\title{
How to Give Birth - According to Hollywood
}

\author{
Sara Persson
}

\begin{abstract}
:
This article examines birth scenes in five mainstream films in order to explore the way norms about birthing are reproduced or challenged. The films are: Juno (Reitman, 2007), Knocked Up (Apatow, 2007), Baby Mama (McCullers, 2008), The Back-up Plan (Poul, 2010) and What to Expect When You're Expecting (Jones, 2012). What do the birthing scenes look like, are they realistic with non-on-set births and does the directors' and writers' gender, age, skin colour and class have any parallels with what is portrayed? The analysis shows that certain norms are upheld in all films; vaginal delivery in hospital, birthing positions of half sitting or laying down and present partners or friends during delivery. Scenes not representing this were depicted as the Other and thus made deviant. Homogeneity in the group behind the camera was found which correlates with certain homogeneity on screen as well. Of all the eight scenes, the women give birth half sitting or laying down in seven, implying a dominance of certain positions. These positions were found to be very common off-screen too, despite the wide range of birthing positions available and recommendations to try different ones during labour. This implies that the practicality for personnel goes beforehand. By using feminist theories on the body and medical studies on births, these findings reveal power structures devaluating female-coded bodies. The results also enhance the importance of analysing patterns of representation in general, but birthing depictions in particular, since these representations can affect people's understanding of how a birth should be in real life.
\end{abstract}

Keywords: childbirth, representation, film, birthing positions, intersectionality

\section{Introduction}

Representation matters because we all get affected by what we see in one way or another (Gaines, 1999; hooks, 1999; Thornham, 2000; Hall, 2013). It is therefore important to question representations, otherwise we might end up with only seeing stereotypes, which "reduces people to a few, simple, essential characteristics" (Hall, 2013, p. 257). Stereotypes and reductions that we further internalise (Thornham, 2000, p. 164). By acknowledging power structures that create certain patterns of representation, both in front of and behind the camera, reductionist depictions can be discovered, which hopefully will lead to different representations in future film. 
In this article birth scenes from five feature films will be analysed with the purpose of exploring what is shown and how in order to acknowledge and problematize representations of birthing in mainstream film. Representation patterns from both behind and in front of the camera will be discussed. All the films chosen are from recommendation-lists for people who are expecting a baby (see details below). The themes explored are: What do the birthing scenes look like in these films, mainly based in American contexts? How do the scenes relate to non-on-set births and is it possible to see connections between the directors' and writers' gender, age, skin colour and class, and the representation of birthing in their films? In order to explore these themes, feminist theories on the body and medical studies on births will be used in combination with cultural- and film theory focusing on representation.

The article starts with a presentation of the films and scenes, why they have been chosen and how they will be used in the analysis. Two sections further structure the paper: the first part exploring how they give birth, while the other one focuses on tracing links between who made the film and representations of birthing. A general discussion is held in the end, connecting the two sections as well as summarising the main findings.

\section{Films, scenes, and selection}

Five films, containing a total of eight birth scenes, have been chosen because they are recommended in three to four lists of movies to watch when one is expecting: Babble: " 5 Realistic Childbirth Scenes From Movies" (Bielanko, 2001). Hollywood: "The 20 Best Pregnancy Movies to Watch While You're Pregnant" (Suarez, no date). Mom Junction: "25 Movies You Need To Watch During Pregnancy" (Arshi, 2017). Parents: "10 Movies to Watch When You're Expecting" (Vengrow, 2015). All of the films have also been mentioned in Glamour's lists of "11 Movie and TV Scenes That Get Labor Unbelievably Wrong" (Eidell, 2016). So, even if these movies and scenes are realistic or not, they are recommended to be watched in several lists. This is the reason why I want to analyse them, their content have the potential to shape many peoples views on birthing. Other scenes were presented in these lists but since this article focus on births relating to present life in feature film, all Science-Fictions scenes were excluded as well as 
representations in series. ${ }^{1}$

The films selected are: Juno (Reitman, 2007), Knocked Up (Apatow, 2007), Baby Mama (McCullers, 2008), The Back-up Plan (Poul, 2010) and What to Expect When You're Expecting (Jones, 2012). Information about the films such as cast, crew and production year is taken from the International Movie Database (IMDb, 2017), if nothing else is stated. I will focus on the birth scenes only and therefore not describe the films' full content. To decide when a birth scene starts can be problematic since a lot of time is set in the hospital before the delivery begins, in some movies. This could be seen as part of the birthing but in order to limit the material, I concentrate on what happens after that the water breaks for the pregnant characters and when their actual delivery is taking place.

All films are comedies or comedy-dramas set in a Western, specifically American, presentday context, spanning from 2007-2012. They are all Hollywood productions except Juno, which is an independent film. ${ }^{2}$ It is part of this essay due to its great box office sales and success internationally and in the USA (IMDb, 2017). Despite that these feature films do not claim to portray life events as "they are", like a documentary, and that depictions might be in a certain way in order to amuse an audience, how they show birthing still matters. These are the popular representations seen by many and therefore they shape several peoples understanding of delivery.

According to cultural theorist Stuart Hall (2013, p. 15) representation means: "using language to say something meaningful about, or to represent, the world meaningfully, to other people". It is a complex process since "meaning can never be finally fixed" and how people interpret what they see will vary (2013, p. 270). Many factors thus take place in shaping someone's mind and therefore filmic representations cannot alone stand for how a person perceives something. However, film is definitely one factor and if the same kinds of representations are shown over and over again, one might wonder if there are no other options out there. In the next section, the birthing scenes will be presented.

In the birth-scene in Juno, the main character with the same name as the film, starred by Ellen Page, gives birth vaginally in a hospital accompanied by her best friend and her mom

\footnotetext{
1 The movie Junior (Reitman, 1994) with a pregnant and birthing Arnold Schwarzenegger in the lead was excluded despite mentioned in two lists, not because it is unrealistic with men giving birth but because it is very rare. Transgender men have experienced pregnancy and birth after female-to-male gender transitioning but they are few (Light et al., 2014).

${ }^{2}$ With a Hollywood production, I mean a production made in the movie industry centre of Hollywood in the USA. More information about the stylistic features and the industry itself can be found in Corrigan and White's The Film Experience, among others (2009).
} 
(Time: $01.25 .10-01.25 .55)$. The scene is only half a minute long and Juno is half sitting, pushing, screaming and crying with her legs spread.

In Knocked-Up the main character Alison (Katherine Heigl) also gives birth at a hospital, half sitting with her legs spread (Time: 01.57.26-2.00.15). While screaming and swearing at all the male characters in the room there is a close-up of her vagina; when the head of the baby is starting to come out, both Alison and her partner Ben (Seth Rogen) show disgust. The newborn baby is later put on Alison's stomach.

Baby Mama has a very short birthing scene after Angie (Amy Poehler) have been screaming and making a scene in the hospital (Time: 01.29.00-01:30.00). She gives birth vaginally, in the same position as Juno and Alison in the previous films whereupon Kate (Tina Fey), that is going to be the mom of the baby (Angie is a surrogate mom), faints. ${ }^{3}$

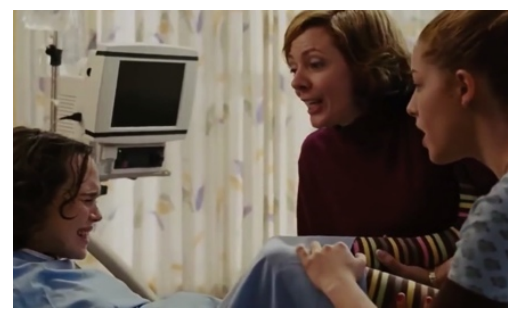

Juno in Juno

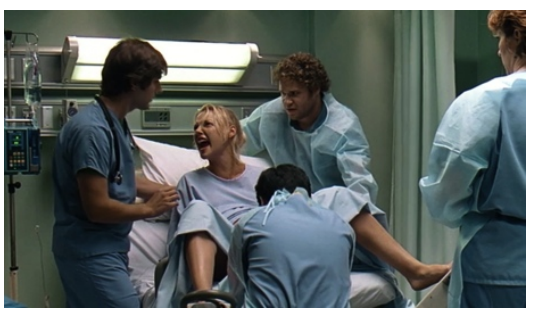

Alison in Knocked-Up

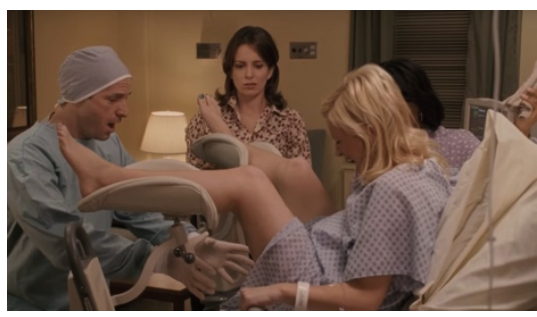

Angie in Baby Mama

In The Back-up Plan, there are two very different birthing scenes. The first one is a home birth where the character of Lori (Maribeth Monroe) gives birth on all four in an inflatable pool, surrounded by chanting and drumming female friends (Time: 01.16.07-01:18.25). A close-up through the water shows us the head of the baby coming out, at the same time as birthing Lori looks at it through a mirror. The pregnant main character, Zoe (Jennifer Lopez), expresses strong feelings of disgust when watching her friend giving birth and just after delivery she faints into the pool. When Zoe is about to give birth herself, it is set in a hospital and the delivery is vaginally while she is half laying down, as the characters in the other films (Time: 01.36.10-01.36.20).

\footnotetext{
${ }^{3}$ All images are screenshots taken by the author if nothing else is stated.
} 


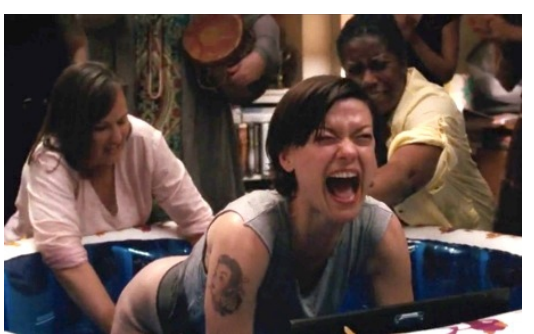

Lori in the pool

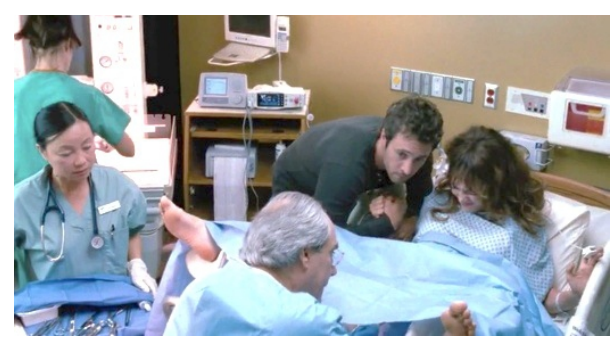

Zoe's final push

There are three birthing scenes in What to Expect When You're Expecting, all taking place simultaneously at the end of the film, a pattern for all the chosen movies (Time: 01.27.0401.33.30). The character Wendy (Elisabeth Banks) has a set birth plan where she wants to give birth vaginally without an epidural but ends up with a caesarean. ${ }^{4}$ Jules (Cameron Diaz) also gives birth in a hospital and starts by sitting up, holding on to a frame but later lays down, half sitting and pushing. The third birthing character, Skyler (Brooklyn Decker), gives birth vaginally to twins and the first one comes out when she is sneezing. Skyler is also the only character that does not seem to be affected by the delivery, not sweating and screaming like the rest.

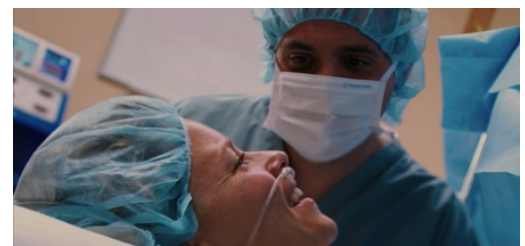

Wendy during the caesarean

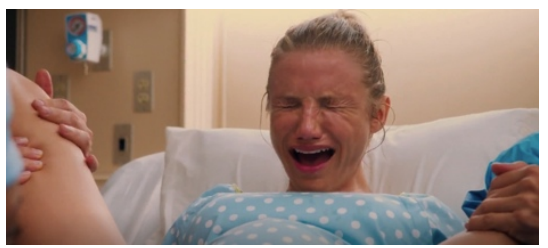

Jules pushing

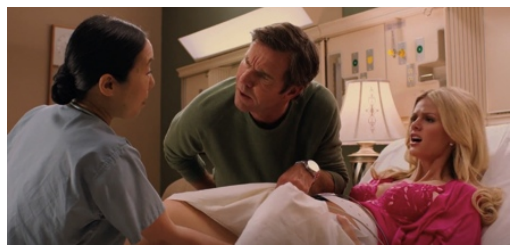

Skyler before sneezing

\section{Part 1: How do they give birth?}

This section will address some particular patterns from the birthing scenes. Firstly, focusing on the birthing positions shown and later addressing how some births are seen as different in relation to others. The studies on birthing are mainly from western contexts, though not only from North America, which is where the films are produced and take place. Some sources are from Sweden, thus a Scandinavian context, which shows that some of the patterns found relate to other western contexts as well. However, it is important to

\footnotetext{
${ }^{4}$ An epidural is a pain-killing drug injected in the back. It is a regional anaesthesia "that blocks pain in a particular region of the body" and it is the most "popular method of pain relief during labour" in the USA (American Pregnancy Association, 2017).
} 
keep in mind that all birthing norms are contextually bound and a larger study would be needed with films from more countries in order to establish more similarities and differences.

\section{Birthing position(s)}

Of all the eight scenes the women give birth half sitting in seven. It is only in The Back-up Plan that Lori gives birth on all four in water, after having switched positions from sitting. Half sitting is only one of many delivery positions and to know what position that is the best for each person beforehand is impossible since every person and delivery is unique (Vårdomsorg, no date). People giving birth are encouraged to try different positions during labour: squatting, on all four, on the knees, laying on the side, standing and so forth (BabyCenter, 2017; Beier, 2018). Yet the half sitting position is the most common one in the movies.

Half sitting is also one of the most common birth positions outside of the film world, according to several studies (Beier, 2018). Having your knees bent helps with expanding the pelvis and it is a good position for the health care personnel, but in this position gravity will not help since the canal the baby is coming out from is facing upwards. It is sometimes needed for the birthing person to lay down or half sit though, especially if the birth is complicated and extra help is required but this is not a majority of the cases (BabyCenter, 2017). A recent study (Björkman and Bucht, 2016), containing a systematic review of 13 scientific articles on birthing positions and their effect on perineal damage, shows that lateral delivery positions (laying on your side) and standing on the knees reduces the risk for perineal trauma. To give birth in the lithotomy position (laying down or half sitting with legs spread) is less preferable in order to avoid ruptures according to the study (2016, p. 35). Björkman and Bucht also stress that the woman giving birth should use a position that is most comfortable for her and that personnel need to be educated in helping women deliver in other positions than laying or half sitting (2016, p. 2).

The scenes portraying these particular positions in all five films can thus be understood as reproducing a general pattern at hospitals, but by doing so they also continue to uphold an understanding of half sitting as the supposedly "only" birthing position. By showing women giving birth half sitting or laying down, with their legs spread, and a doctor, midwife or nurse between those legs, all the other potentially better positions are made invisible. If 
you do not know that other positions are available, ones that also might be better for you, the chances that you will ask to change to a more comfortable and potentially better position is low. So why is this position the most common one when it is not necessarily the best one?

As part of feminist projects through a long time, the "patriarchy's control of women through their bodies" have been a major issue (Thornham, 2000, p. 155). A dualistic thinking, where things and behaviours have been divided and valued, has created a society where women are seen as "the Other" to men, inferior and passive (2000, p. 160). Men with power have through laws and restrictions conducted how women "should be", but also others who do not conform to a white, male and heterosexual norm, in order to keep women and other non-normative in place (Thornham, 2000; Dolezal, 2010). Though "woman" as a fixed category does not exist, it is an "instable and incoherent one, 'historically, discursively constructed, and always relative to other categories which themselves change"' (Thornham, 2000, p. 122). A unifying category has been created by the feminist movement, in order to differentiate women from men as well as to unite, which later received critique since it excluded differences within the group (hooks, 1999, p. 314; Thornham, 2012, pp. 119-123).

Why a birthing position, that might not be ideal for the person giving birth, has become the norm can, therefore, be understood as a part of a patriarchal context, where what is best for women is not at the centre of attention. As a result of this, a lack of research, in general, exist when it comes to diseases and treatment of female coded bodies and especially on how different birthing positions affect people giving birth (Carlstedt, 1992; Brännström et al., 2012; Björkman and Bucht, 2016; SBU, 2016). In summary; there is no efficient research made on birthing positions and even though it appears to be a common understanding that women can and should switch positions during delivery, the practicality for the personnel seem to be more valued.

\section{The Other}

As mentioned earlier, it is only in one scene that a birth outside of a hospital takes place as well as a birth in a different position than half sitting. This scene, in The Back-up Plan, is portrayed as something crazy and different compared to "regular" hospital births. Lopez's 
character Zoe enters the building where the birth is to take place with her date Stan (Alex O'Loughlin). They are not supposed to stay but get invited to join. While they look around in the building filled with women, one breastfeeding a quite grown child, Stan asks: "How long do we have to stay here?" clearly uncomfortable with the situation. Zoe is uncomfortable too and responds: "Just wait till it starts (the birth, my note) and then we'll sneak out" (Time: 01:15.30-01:16.55). Zoe shows disgust throughout the delivery, but is not allowed to leave because she is the "focal point" for Lori. The chanting gets louder and louder and Lori starts sounding like a sheep while dragging Zoe down towards her. The baby's head is coming out and she screams: "Give me a mirror I want to see it!" whereupon Zoe answers in panic "no you don't!" In the end, everybody is screaming: Lori, Stan, Zoe and all the chanting women in the background. The scene ends when the baby is born and Zoe faints and falls into the pool.

The scene is meant to be entertaining and funny but since it is made in such a contrast to Zoe's own birth, in a hospital with doctors and nurses around instead of chanting hippie women, the homebirth scene becomes a representation of Othering. Otherness is built on difference and binary oppositions are always in relation to power, by constructing a self or a "we" someone or something else becomes the Other (Hall, 2013, pp. 234-237). Hall focuses on race and how white people have turned people of colour into racialized others, deemed lazy, primitive, violent or over sexual, in order to be able to domesticate them as part of colonial and imperialist projects (2013, pp. 239-251). Othering thus means to use stereotypes, which "reduces, essentializes, naturalizes and fixes 'difference", in order to maintain a "social and symbolic order" but also to create a certain "l" and "we" (2013, p. 258). The Other is deviant and not "normal like us", based on this specific order and seeing people in a simplistic way erases complexity as well as makes clear distinctions from oneself or a group.

In the home birth scene, I argue that Lori and the whole birthing ceremony is othered in relation to Zoe's birth, at a hospital and in the most common birthing position. Making Lori and homebirth a funny joke reduces the possibility of subversive potential that the scene, portraying a woman switching positions at home, could have. A good thing is that the scene takes place at all. If it would not be there, all films in this selection would show only hospital births and birthing positions of half sitting or laying down. In connection to othering, seven out of eight births portrayed in these scenes are vaginal. Only Elisabeth 
Banks character, Wendy, has a caesarean after all other options of giving birth vaginally are out. Giving birth "naturally" (vaginally) seems to be the norm.

Norms of giving birth vaginally or by caesarean are context bound. In many Latin American countries, giving birth by caesarean is the standard. In Brazil, for example, about $50 \%$ of all births are with C-section, whereas in the USA the number is $30.3 \%$ and in Sweden $17.3 \%$, according to the World Health Organization's report from 2010 (Gibbons et al., 2010, pp. 18-19). Birgitta Hellmark Lindgren writes about pregnancy as a field of conflicting debates and means that in Sweden it is an ideal of "natural and hospitalized birth" (2006, p. 233). To ask for a caesarean thus implies that midwives and physicians are challenged, but also "a perspective on femaleness in which vaginal birthing is a core value" (2006, p. 233). Mainly showing vaginal, hospitalized births and only one caesarean, which the woman does not want to have, can therefore be understood as an othering of both home- and C-section births. Wendy's C-section is also the only birth that is shown as having implications. After delivery, she is losing a lot of blood and for a moment it is unclear if she will survive (Time: 1.34.15-1.37.25).

Considering that all films are set in American contexts, where about one third of all deliveries are by caesarean, only depicting one C-section, that is against the woman's will and have a potentially deadly outcome, makes it seem far more unusual and different than it is outside the film world. This implies that the Western norm of vaginal delivery is upheld. This does not mean that it is negative to represent vaginal delivery, but that it is problematic with too homogenous representations since it leaves out other options.

\section{Abjection}

Another finding in the material is that several characters show disgust or faints during the deliveries. In The Back-up Plan, Zoe faints in the inflatable pool after Lori's delivery and Kate collapses while Angie is giving birth in Baby Mama. Before Zoe faints she has shown disgust through body language, grimacing, and speech, similar to both Alison's and Ben's reactions in Knocked-Up. Where does this repulsion against the birthing female body come from? Is it just a cinematic tool to create a comic situation or does it imply something else as well? 
Based on work by Julia Kristeva and Anne McClintock, Robyn Longhurst (2001, p. 28) discusses the term abject, which "provokes fear and disgust because it exposes the border between self and other". What is understood as abject depends on context and in some cultures pregnant, disabled and lactating bodies are seen as abjects since they are perceived as out of control in a world with a solid, able-bodied, rational man as the norm (2001, p. 26). Body fluids, in general, can also be abjects. Anthropologist Mary Douglas' work in Purity and Danger (1966) focuses on the social construction of what is perceived as dirty. Especially body leakages are seen as challenging borders and therefore order, which leads to fluids from the body, like urine and faeces, being treated as something disgusting or dangerous (1966, pp. 172-173).

The disgust shown in several scenes in the films can hence be understood as coming from a fear of challenges to societal borders in a patriarchal society. Especially the baby's head causes this repulsion, both in The Back-up Plan when Zoe sees the head coming out of Lori's vagina, and in Knocked-Up. In a society where the ideal is an unattainable image of a solid, non-leaking, rational male subject, a birthing woman can be seen as the ultimate abject. The repugnance that the characters show proves this fear and loathing for fluids and bodies that do not conform to this unachievable ideal image.

This section has addressed how the birth scenes are represented with a special focus on birthing positions. All the five films in the selection showed mainly vaginal births, at hospitals in the lithotomy position. Other forms of birthing, either C-section or births at home were represented differently and could, therefore, be seen as othered. A pattern of showing disgust during delivery was also found, which reinforces the construction of abjects in a patriarchal society. The next section will address if and how potential patterns behind the camera affects what is represented.

\section{Part 2: Tracing links between patterns behind the camera and representations of birthing}

This section will explore if it is possible to see connections between the directors' and writers' gender, age, skin colour and class, and the representations of birthing in their films. With connections I mean if there are any patterns of representations behind the camera (directors and writers) and in front of the camera (characters). In order to explore 
this, I have categorised directors, writers, and characters based on information mainly found on IMDb (2017). This method has two major limitations, categorisation in general and the focus on only directors and writers. After addressing these limitations a discussion of why it is still important to do this kind of study will be held, before the paper ends with the analysis part "Behind and in front of the camera" and a conclusion.

Categorisation is problematic since the line is thin between upholding created structures and challenging them (Alarcón, 1990; Haraway, 1991; McCall, 2005; Griffin, 2006). While naming or creating something, other aspects are left out. Gender, age, class and race as well as other categories that are used to define people, are thus socially and culturally constructed and get their meaning contextually. Despite the knowledge of these issues, this part of this paper will address potential connections between representation behind and in front of the camera, as well as use categorisation. This is done because capitalist, racists and sexist structures still affect what is represented (Kuhn, 1982; Gaines, 1999; hooks, 1999; Kaplan, 2001). However, due to the awareness and belief in the social and cultural construction of our understanding of categories, I will clarify how I have made these distinctions in this study throughout the section.

To only focus on the directors and writers is limiting the study since many people are part of making a film and other aspects affect the outcome on screen. The critique against auteurism, "that the film director is the single force responsible for the final film", is not new and highlights the fact that film is a collectively produced medium (Mayne, 1981, pp. 3849). One's gender, age, skin colour, class or any other factor does not have to determine the outcome of the film either, even if connections many times are present (Mayne, 1981; Tejle, 2016). Other factors that can affect what is portrayed are financial decisions, producer(s) opinions or sponsors requirements. A budget cut could, for example, mean that a scene planned to take place in a certain location needs to be moved. Nevertheless, since the majority of films have been made by privileged, white men, something that has had consequences on what is represented and how, questions of authorship are important (Thornham, 2012, pp. 27-28).

Literary scholar Judith Fetterley (1978) writes about American literature, women's relation to it and how men have been dominating and thus equated the experience of being American with being male. "As readers and teachers and scholars, women are taught to think as men, to identify with a male point of view, and to accept as normal and legitimate 
a male system of values, one of whose central principles is misogyny" (1978, p. xx). Fetterley means that men have created the American literary canon and that this has led to representations of men for men, with female characters portrayed in a way that upholds patriarchy. Based on the work by Adrienne Rich, re-vision, "the act of looking back" and entering a text from a new perspective is needed in order to step away from this unequal literary creation and its content, one should be a "resisting reader rather than an assenting reader", according to Fetterley (1978, p. xix, xxii). By acknowledging and problematizing what is shown and how in the eight birthing scenes, my aim is to entering these depictions from another angle.

Connected to audiovisual media, film theorist Laura Mulvey (1975, p. 6) means that "a patriarchal society has structured film form". This structure has created women as Others and film form is built in a certain way as to enjoy depictions of females: "In a world ordered by sexual imbalance, pleasure in looking has been split between active/male and passive/female" (1975, p. 11). Women are displayed as sexual objects to be looked at in contrast to the active males. bell hooks (1999) and Jane Gaines (1999) both add other dimensions of power to what that is shown and how. hooks addresses black female spectatorship, representation and how feminist film critique has left out race in their focus on sexism, while Gaines points out that normative sexuality is constructed as hetero with a clear division between male and female, which excludes lesbians and women of colour among others. This implies that who makes the art have an effect on what it represented and how. With this in mind, I will now explore potential patterns of representations behind and in front of the camera.

\section{Behind and in front of the camera}

Of the directors, all five are men, four from North America (USA and Canada) and one from England (see clarification on definitions below). They are between the ages of 39 and 63 years old and their skin colour is white. I have defined the skin colour of the directors and writers based on pictures found on the Internet when searching on their names. Skin colour in itself does not say anything about a person but can have an importance when one is aware of racial structures in society, which have lead to privileges for white people (Hall, 2013, pp. 239-269). Just like with over-representation of men behind and in front of 
the camera, light-skinned people have dominated what to show and how in the film industry (hooks, 1999; Hall, 2013). Since I do not have information on how all of the characters, writers and directors identify themselves, I base my division of gender on the pronouns used, in the films for the characters, and in interviews or in other sources, such as the International Movie Database, for the directors and writers (ArtisanNewsService, 2007; TalkinToU1, 2010; emPOWERme.tv, 2012; gofobo, 2012; MacKay, 2013; IMDb, 2017; TODAY, 2017). However, some direct statements have been found, such as when director Kirk Jones says "I am a guy", in an interview about What to Expect When You're Expecting (Clever News, 2012).

Two of the directors, Apatow and McCuller, have also written the scripts for their films while the other productions have female writers: Diablo Cody (Juno), Kate Angelo (The Back-up Plan) and Shauna Cross, Heather Hach and Heidi Murkoff for What to Expect When You're Expecting, which is also based on Murkoff's book series with guides for parents on "what to expect" when having a baby (What to Expect, 2017). Six out of seven writers are from the USA, no nationality information was found on Kate Angelo. In general, it was easier to find information about the male directors than the female writers, despite that they also have done a large amount of work within the film industry. There were no biographies at all for Cross or Angelo on IMDb and no age information for three of the five female writers (IMDb, 2017). This can be seen as a common trend where female film workers get less attention, less payment and less recognition than male film workers (Women Make Movies, 2017). In summary, the directors and writers form a homogenous group of white, middle-aged Americans where men are in majority. This reflects the American film industry at large, where middle-aged, white men have most of the power (Gaines, 1999; hooks, 1999; Kaplan, 2001; Hall, 2013). However, that three of the films have female writers goes against this male Hollywood domination to a certain extent, but the lack of information about female film workers still proves a gender issue.

The birthing characters consist of seven white-skinned women in their 30's from the upperor middle class. Only one is Latin (Jennifer Lopez who is starring Zoe in The Back-up Plan) and only one is a teenager (Ellen Page starring Juno in the film with the same name). Class is, like any other category, not fixed and hard to define and in this paper, I base my definition on the employment and housing of the characters as well as direct statements where their class belonging sometimes is made quite clear. Such as when 
Wendy's husband Gary (Ben Falcone) needs to get a doctor's attention and asks his father (Dennis Quaid) if he can have his "money roll". Or when Kate in Baby Mama hears about the extremely high fee for a surrogate mother and later pays the sum.

A majority of the characters give birth with their male partner present (five out of eight) and in the other three scenes with female friends or parents. All these people present at delivery are white. There are characters of colour in the films but not as main characters in the delivery scenes, except for doctors and nurses. bell hooks means that even when representations of black women are present in a film, their "bodies and being" are to serve and enhance especially white characters (1999, p. 310). This pattern can be found in this material, since the non-white characters present in the eight delivery scenes are helping the mainly white women to give birth.

As mentioned above, friends or a partner is present at delivery in all films. Having someone present at delivery have been proved positive for the one giving birth, with faster delivery, less use of pain killing drugs and fewer caesareans needed as a result (SBU, 2016). Having a partner or a friend present is not something to take for granted though. Obstetric care has changed a lot the last decades in many Western countries, and the move from homes to hospitals have also meant that the traditional female support got lost (SBU, 2016). These films thus take a stand for a present father, friend or family member at delivery, a stand that can be understood as following the latest research on how to obtain the best circumstance for the woman in labour. However, if a present partner always is the best thing has been contested since it is unclear if they stress their partners more than help them relax (Odent, 2008; Wallis, 2013). This is also hard to tell from the scenes selected, since almost all female characters are portrayed as hysterical, both before and during delivery, despite a present partner. Hysterical births, together with the issues of having present partners and using painkillers or not, are interesting themes to explore for future research.

Heterosexuality is the norm in a majority of the films. Male partners or boyfriends are present in five out of eight scenes and if they are not present there is an explanation, as for Paulie's absence in Juno. In the other stories, the birthing character's partner might not be part of the pregnancy at all, like Carl (Dax Shepard), the surrogate mom Angie's husband in Baby Mama. So except for the domination of white characters, a heterosexual norm is upheld. The homogeneity of the group behind the camera can hence be reflected 
on screen as well, to a certain extent, representing mainly white, middle- or upper class leads in similar ages. This proves that the representation behind the camera is important for the outcome on screen. The ages of the characters can be explained by the fact that most births take place within a particular age span (OECD Family Database, 2018, p. 1). However, that does not mean that alternative stories cannot be told, which applies to other aspects as well. For example, more diverse births and more non-white leads could and should be represented in these scenes, if dominant structures are to be challenged, leading to more varied representations available.

As pointed out by Gaines (1999) and hooks (1999), domination of whiteness and heterosexuality is not unusual but therefore not unproblematic. Together with Mulvey, who suggests us to deconstruct the gaze and Fetterly that tells us to be resisting readers, they all promote new ways of acting in order to challenge white, patriarchal powers that structures and thus affect what is shown or written. A concrete outcome of these feminist theories is the A-mark. Films can receive this marking by passing either the Bechdel Wallace test, where two named female characters have to talk to each other about something else than men, or Chavez Perez test, where two non-white characters have to talk to each other about something besides crime (Tejle, 2016).

Even though these rankings do not provide any deep analyses of film content, they are eye-openers for norms and structures within film. Therefore it is problematic that not more films pass these two, very simple tests. Only 4482 films out of 7760 pass the Bechdel Test for example, which is just a little bit over half (57.8\%), of all the productions in the test (Bechdel Test Movie List, 2018). This proves that much work is still needed in order to create a more equal movie industry with varied representations, which reflect more people's experiences. We can hence try and change our view on what we see or question and try to change the representations available to us. This paper has been part of these strategies when exploring how births are portrayed in mainstream film and how the creators affect the outcome.

\section{Conclusion}

This article shows that certain norms are upheld in the five films analysed; vaginal delivery in hospital, birthing positions of half sitting or laying down and present partners or friends 
during delivery. Scenes not representing this were othered and thus made deviant. Of all the eight scenes, the women gave birth half sitting or laying down in seven, implying a dominance of certain positions. These positions were found to be very common off-screen too, despite the wide range of birthing positions available and recommendations to try different ones during labour. This implies that the practicality for personnel go beforehand as well as reveals power structures that devaluate female-coded bodies. Homogeneity in the group behind the camera was found, which correlates with certain homogeneity on screen as well. The domination of whiteness, among directors, writers and the main characters in the birthing scenes, does therefore not challenge white supremacy in Hollywood film. However, the general gender bias in the American movie industry, with a majority of men, was partly challenged by the number of female screenwriters in the productions. Further, heterosexuality was upheld as a norm in most scenes and a theme of repulsion against the birthing female body detected, reinforcing the construction of abjects in a patriarchal society.

The findings from this study enhance the importance for future research to analyse patterns of representation in general, both behind and in front of the camera, but birthing depictions in particular since these representations can affect people's understanding of how a birth should be in real life.

\section{References}

Alarcón, N. (1990) 'The Theoretical Subjects of This Bridge Called My Back and AngloAmerican Feminism', in Anzaldúa, G. (ed.) Making Face, Making Soul/Haciendo Caras: Creative and Critical Perspectives by Feminists of Color. San Francisco: Aunt Lute Books, pp. 356-366.

American Pregnancy Association (2017) Using Epidural Anesthesia During Labor:

Benefits and Risks. Available at: http://americanpregnancy.org/labor-andbirth/epidural/ (Accessed: 26 May 2017).

Apatow, J. (2007) Knocked Up. USA: Warner Brothers Pictures.

Arshi (2017) 25 Best Pregnancy Movies You Need To Watch. Available at: https://www.momjunction.com/articles/movies-you-need-to-watch-duringpregnancy_00385377/\#gref (Accessed: 24 May 2017). 
ArtisanNewsService (2007) 'Juno Writer Diablo Cody Reveals Inspiration'. Available at: https://www.youtube.com/watch?v=WqyQqE9Rff4 (Accessed: 22 October 2018).

BabyCenter (2017) Positions for labor and birth, September. Available at: https://www.babycenter.com/0_positions-for-labor-and-birth_10309507.bc (Accessed: 28 May 2017).

Bechdel Test Movie List (2018) Stats and graphs. Available at: https://bechdeltest.com/statistics/ (Accessed: 5 June 2018).

Beier, C. (2018) Best Labour And Birth Positions. Available at: http://www.givingbirthnaturally.com/birth-positions.html (Accessed: 7 June 2017).

Bielanko, M. (2001) 5 Realistic Childbirth Scenes From Movies. Available at: https://www.babble.com/pregnancy/5-realistic-childbirth-scenes-frommovies/ (Accessed: 24 May 2017).

Björkman, A. and Bucht, H. (2016) Does the birth position affect the occurrence of perineal injury? Karolinska Institutet.

Brännström, M., Hägglund, L., Fürst, C. J. and Boman, K. (2012) 'Unequal care for dying patients in Sweden - A comparative registry study of deaths from heart disease and cancer', European Journal of Cardiovascular Nursing. doi: 10.1016/j.ejcnurse.2011.06.007.

Carlstedt, G. (1992) Kvinnors hälsa - en fråga om makt. Falun: ScanBook AB.

Clever News (2012) 'Director Kirk Jones Talks What To Expect When You're Expecting'. Available at: https://www.youtube.com/watch?v=mBTcUye-YHA (Accessed: 22 October 2018).

Corrigan, T. and White, P. (2009) The Film Experience: An Introduction. Basingstoke: Palgrave Macmillan.

Dolezal, L. (2010) 'The (In)visible Body: Feminism, Phenomenology, and the Case of Cosmetic Surgery', Hypatia, 25(2), pp. 357-375.

Douglas, M. (1966) Purity and Danger: An analysis of concepts of pollution and taboo. London: Routledge, Kegan Paul.

Eidell, L. (2016) 11 Movie and TV Scenes That Get labour Unbelievably Wrong. Available at: https://www.glamour.com/story/movie-and-tv-scenes-that-get-labor-give-birthwrong-video (Accessed: 24 May 2017). 
emPOWERme.tv (2012) 'What to Expect When You're Expecting Screenwriter Shauna Cross'. Available at: https://www.youtube.com/watch?v=jDz8vpURORc (Accessed: 22 October 2018).

Fetterley, J. (1978) 'Introduction: on the politics of literature', in The Resisting Reader. Bloomington: Indiana University Press, pp. xi-xxvi.

Gaines, J. (1999) 'White Privilege and Looking Relations: Race and Gender in Feminist Film Theory', in Thornham, S. (ed.) Feminist Film Theory: A Reader. New York: University Press.

Gibbons, L., Belizán, J. M., Lauer, J. A., Betrán, A. P., Merialdi, M. and Althabe, F. (2010) 'The Global Numbers and Costs of Additionally Needed and Unnecessary Caesarean Sections Performed per Year: Overuse as a Barrier to Universal Coverage', World Health Report (2010) Background Papers, pp. 1-31. doi: 10.1017/CBO9781107415324.004.

gofobo (2012) 'What To Expect When You're Expecting - Red Carpet Premiere - Heather Hach (Screenwriter)'. Available at: https://www.youtube.com/watch? v=TtHGrndmVfw (Accessed: 22 October 2018).

Griffin, G. (2006) 'Gendered Cultures', in Davis, K., Evans, M., and Lorber, J. (eds) Handbook of Gender and Women's Studies. London: Sage, pp. 73-91.

Hall, S. (2013) Representation. Los Angeles: Sage.

Haraway, D. (1991) 'A Cyborg Manifesto: Science, Technology, and Socialist-Feminism in the Late Twentieth Century', in Simians, Cyborgs and Women: The Reinvention of Nature. New York: Routledge, pp. 149-181.

Hellmark Lindgren, B. (2006) Pregnoscape. Den gravida kroppen som arena för motstridiga perspektiv på risk, kön och medicinsk teknik. Uppsala University. hooks, bell (1999) 'Oppositional Gaze: Black Female Spectators', in Thornham, S. (ed.) Feminist Film Theory: A Reader. New York: University Press, pp. 307-320. IMDb (2017) International Movie Database (IMDb). Available at: http://www.imdb.com/ (Accessed: 25 May 2017). Jones, K. (2012) What to Expect When You're Expecting. USA: Lionsgate. Kaplan, A. E. (2001) Women and Film: Both Sides of the Camera. London: Routledge. Kuhn, A. (1982) Women's Pictures: Feminism and Cinema. London: Verso. Light, A. D., Obedin-Maliver, J., Sevelius, J. M. and Kerns, J. L. (2014) 'Transgender Men 
Who Experienced Pregnancy After Female-to-Male Gender Transitioning', Obstetrics \& Gynecology, 124(6), pp. 1120-1127. doi:

10.1097/AOG.0000000000000540.

Longhurst, R. (2001) Bodies: Exploring Fluid Boundaries. London: Routledge.

MacKay, V. (2013) 'Heidi Manning - Interview On Book What To Expect When You're Expecting'. Available at: https://www.youtube.com/watch?v=r2ZRamd7Ahk (Accessed: 22 October 2018).

Mayne, J. (1981) 'The Woman at the Keyhole: Women's Cinema and Feminist Criticism', New German Critique. Duke University Press, (23), p. 27. doi: 10.2307/487935.

McCall, L. (2005) 'The Complexity of Intersectionality', Signs: Journal of Women in Culture and Society. The University of Chicago Press, 30(3), pp. 1771-1800. doi: 10.1086/426800.

McCullers, M. (2008) Baby Mama. USA: Universal Pictures.

Mulvey, L. (1975) 'Visual Pleasure and Narrative Cinema', Screen. Oxford University Press, 16(3), pp. 6-18. doi: 10.1093/screen/16.3.6.

Odent, M. (2008) A top obstetrician on why men should NEVER be at the birth of their child. Available at: http://www.dailymail.co.uk/femail/article-559913/Aobstetrician-men-NEVER-birth-child.html (Accessed: 29 May 2017).

OECD Family Database (2018) Age of mothers at childbirth and age-specific fertility. Poul, A. (2010) The Back-up Plan. USA: CBS Films.

Reitman, I. (1994) Junior. USA: Universal Pictures, Northern Lights Entertainment.

Reitman, J. (2007) Juno. USA: Fox Searchlight.

SBU (2016) Behandling av förlossningsskador som uppkommit efter vaginal förlossning. En kartläggning av systematiska översikter. Stockholm. doi: ISBN 978-91-8541393-5.

Suarez, A. L. (no date) The 20 Best Pregnancy Movies to Watch While You're Pregnant. TalkinToU1 (2010) 'Kate Angelo Writer The Back-up Plan Movie'. Available at: https://www.youtube.com/watch?v=eiz719xAcPU (Accessed: 22 October 2018).

Tejle, E. (2016) A-list. Available at: http://www.a-listfilm.com/ (Accessed: 29 May 2017).

Thornham, S. (2000) Feminist Theory and Cultural Studies. London: Arnold.

Thornham, S. (2012) What if I Had Been the Hero? Investigating Women's Cinema. 
London: Palgrave Macmillan.

TODAY (2017) 'Judd Apatow: "Knocked Up” Was "Such A Great Moment"'. Available at: https://www.youtube.com/watch?v=XZoJdkNdQy0 (Accessed: 22 October 2018).

Vengrow, B. (2015) 10 Movies to Watch When You're Expecting. Available at: http://www.parents.com/pregnancy/my-\%0Dlife/preparing-for-baby/10movies-to-watch-when-youre-expecting/ (Accessed: 24 May 2017).

Vårdomsorg (no date) Förlossningsställningar. Available at: http://vårdomsorg.se/liknande/forlossningsstallningar-1563 (Accessed: 6 June 2018).

Wallis, L. (2013) How it became almost mandatory for dads to attend the birth - BBC News. Available at: https://www.bbc.co.uk/news/magazine-21701683 (Accessed: 29 May 2017).

What to Expect (2017) About Heidi. Available at: http://www.whattoexpect.com/home/about-the-author.aspx (Accessed: 25 May 2017).

Women Make Movies (2017) Film Facts. Available at: http://www.wmm.com/resources/film_facts.shtml (Accessed: 30 May 2017). 